\title{
アイソタクチックポリプロピレンの接着強さにおよぼす ジカルボン酸存在下の加熱空気表面処理の影響
}

（1975 年 3 月 26 日 受 理）

\author{
新 保 正 樹・喜田村哲二・木 田 宏*
}

ポリプロピレンを加熱空気によって表面処理するにあたって，あらかじめポりプロピレンに有機ジカ ルボン酸を添加すると，加熱空気による表面酸化が促進され，接着強さが向上した。

この過程でメチレン鎖のくり返し数 $(n)$ が 0 〜 8 の有機ジカルボン酸を添加し, その処理効果を調ベ た結果， $n: 2 \sim 4$ の間ではく離強さが最大となることを認めた。またこの領域で球晶直径は最小，X線 散乱による(040) 面の反射強度は最大となった。

\section{1 緒言}

既報1)ではポリオレフィンの加熱空気による表面処理とその機 構を調べ，ポリオレフィンに含窒素錯化合物を添加するとその表 面処理効果がいちじるしく促進されることを明らかにした。

本報では加熱空気による表面処理にさいして，有機ジカルボン 酸の添加がその処理作用をいちじるしく促進するばかりでなく， ポリプロピレンの結晶性にいちじるしい影響を与え, 表面処理効 果と結晶性および有機ジカルボン酸の化学構造との間によい相関 があることが明らかとなったので以下報告する。

\section{2 実験}

\section{1 試 料}

試料ポリプロピレンはすべて既報12) と同一のアイソタクチッ クポリプロピレン（以下 IPP と略記する）を用いた。その密度, 分子量, 分岐度および結晶度は既報 ${ }^{1}$ に示した。添加した有機脂 肪酸は, シュウ酸, マロソ酸, コハク酸, グルタル酸, アジピ ン酸, アゼライン酸, セバシン酸, マレイン酸, テレフタル酸, 1,4-シクロヘキサンジカルボン酸およびアジピン酸ナトリウム， コハク酸ナトリウムで，いずれす試薬一級品を用いた。

表面処理後の接着す既報 ${ }^{122)}$ と同じェポキシポリアミド接着剂 を用い, ‘被着体も既報 ${ }^{1) 2}$ ) と同一の鋼板（SPCC-SD，新日鉄）を 用いた。接触角や臨界表面張力の測定に用いた溶剤もすべて既 報12)と同一とした。

\section{2 測 定}

IPP 表面処理法も既報 ${ }^{1)}$ と同じライスター熱風機により $2 \times 40$ $\mathrm{mm}$ のノズルから $600^{\circ} \mathrm{C}$ の加熱空気をあてた。表面処理後の IPP の極性基の検出は回折格子型赤外分光光度計によった ${ }^{12)}$ 。

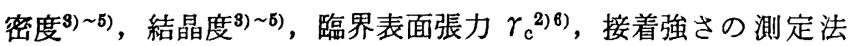

* 関西大学工学部, 564 吹田市千里山東

1）新保正樹, 水本康博, 喜田村哲二, 高分子論文集, 投稿中.

2）新保正樹，小林俊夫，高分子化学，28，604(1971).

3) F. P. Price, J. Chem. Phys., 19, 937 (1951).

4) J. B. Nichols, J. Appl. Phys., 25, 840(1954).

5) G. Natta, Ind. Plast Mod., 10, 40(1958).
のほか, 試料への有機ジカルボン酸の混練方法, 試料の接着方法 いずれも既報1)と同一である。

$\mathrm{X}$ 線散乱はガイガーフレックス $2011 \mathrm{X}$ 線回折装置(理学電気製) を用い， $30 \mathrm{kV}, 10 \mathrm{~mA}$ ，カウント数 $2000 \mathrm{~Hz}$ で測定した。

\section{3 結果および考察}

3.1 ポリプロピレンの表面処理によるはく離強さの変化

既報1)ではポリオレフィンの加熱空気による表面処理にあたり， 種々な含窒素錯化合物を添加すると，その表面処理効果がいちじ るしく促進されることを明らかにした。

本報ではこの錯化合物のかわりに構造を異にする有機ジカルボ ン酸を添加すると, IPP の表面処理がいちじるしく促進されるこ とが認められた。これらジカルボン酸の構造と処理後 IPP のは

く離強さ, 臨界表面張力との関係を調べた。

図1にメチレン鎖の長さを異にする $\alpha, \omega$-ジカルボン酸 $\left(\mathrm{HOOC}-\left(\mathrm{CH}_{2}\right)_{n}-\mathrm{COOH}\right) 6$ 種 $(n=0,1,2,3,4,7)$ を添加した IPP と, アニールした IPP を加熱空気処理したもののはく離強さ を示した。

図のようにコハク酸 $(n=2)$, グルタル酸 $(n=3)$ およびアジ ピン酸 $(n=4)$ の添加はいずれも表面処理効果を強めるが，その ほかのものとアニールした IPP は表面処理の効果は弱い。

図 2 にはコハク酸 $(n=2)$ およびアジピン酸 $(n=4)$ 添加物 と,アニールおよび急冷した IPP の臨界表面張力 $\gamma_{\mathrm{c}}^{2) 6)}$ を示し た。図のようにコハク酸扰よびアジピン酸添加物は $r_{\mathrm{c}}$ b大きく， 急冷した試料がこれにつぎ，アニールして結晶を生長させたもの の $r_{\mathrm{c}}$ がもっとも小さい。

これらの結果は図 1 に示したはく離強さと定性的には相関があ るといえよう。

\section{2 添加物による結晶状態の变化}

IPP に適当な構造をもつ有機ジカルボン酸を添加すると，加熱 空気による表面処理効果をいちじるしく促進する。この間におけ る結晶状態の变化を偏光顕微鏡によって追跡した。

6) W. A. Zisman, "Contact Angle, Wettability and Adhesion”, 1, (1964). 


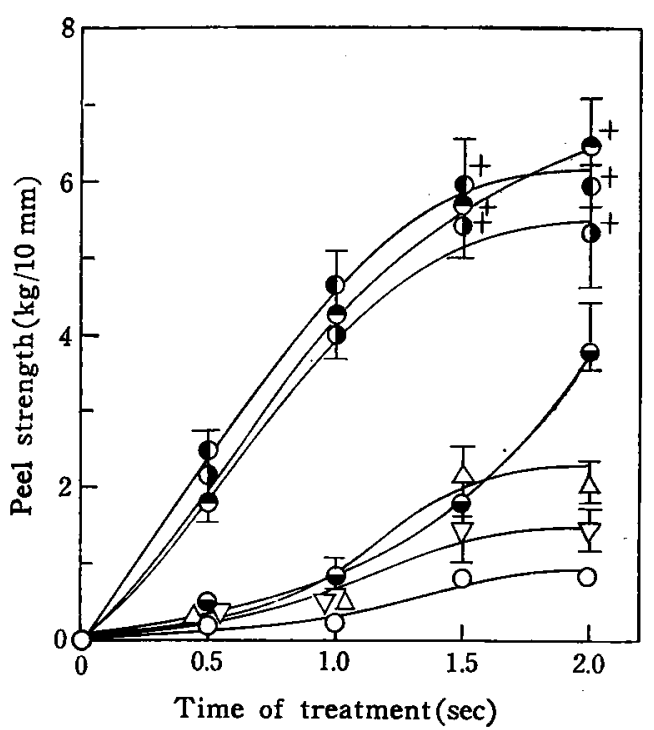

Fig. 1 Peel strength of filled IPP under hot air treatment.

$\nabla:$ IPP filled with oxalic acid

$\left(\mathrm{CH}_{2}\right)_{n}(\mathrm{COOH})_{2}$

$\triangle:$ IPP filled with malonic acid

$n=0$

O : IPP filled with succinic acid

$n=1$

$\theta$ : IPP filled with glutaric acid

$n=2$

D : IPP filled with adipic acid

$\odot$ : IPP filled with azelaic acid

$n=3$

$n=4$

$O: \operatorname{IPP}$ (annealed)

$+:$ Adherend failure

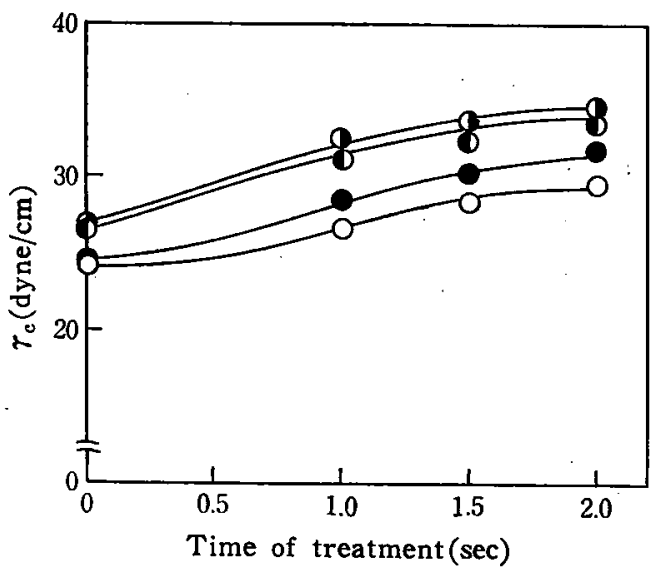

Fig. $2 \gamma_{\mathrm{c}}$ of filled IPP under hot air treatment
(1) IPP filled with succinic acid
D : IPP filled with adipic acid
: IPP (quenched)
$O: \operatorname{IPP}$ (annealed)

すなわちシュウ酸 $(n=0)$ (Plate 1- $(\mathrm{A}))$ 打よびマロン酸 $(n=$ 1)（球晶状況がは注同様であるため写真を省略）添加物いずれる 極度に発達した球晶が認められる。これに対してコハク酸（ $n=$ 2) (Plate 1-(B))，グルタル酸 $(n=3)$ およびフジピ酸 $(n \stackrel{1}{=}$ 4) 添加物（ともに球晶状態がハク酸添加物に近いため写真を 省略）では球晶はきわめて小さく，その直径むすべて $10 \mu$ 以下 となった。

これに対してアゼライン酸 $(n=7)$ (Plate 1- $(\mathrm{C})$ ) 添加物は $30 \mu$ 程度の球晶直径をるち, 図 2 に示した急冷 IPP と同程度の

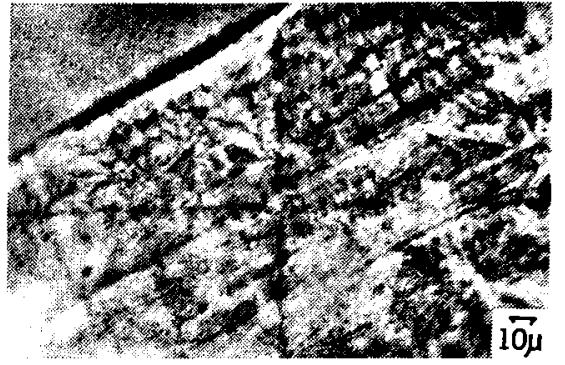

(A) IPP filled with $0.5 \mathrm{wt} \%$ oxalic acid (Peel strength : $1.5 \mathrm{~kg} / 10 \mathrm{~mm}$ )

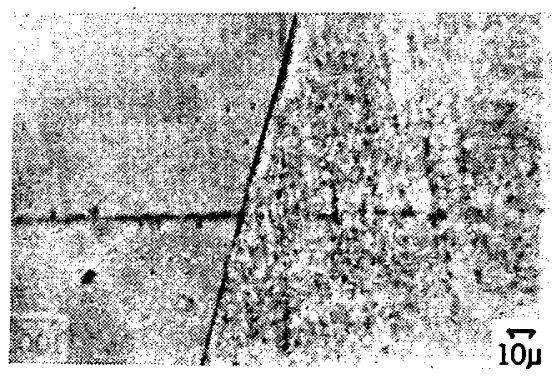

(B) IPP filled with 0.5 wto succinic acid (Peel strength : $7 \mathrm{~kg} / 10 \mathrm{~mm}$ )

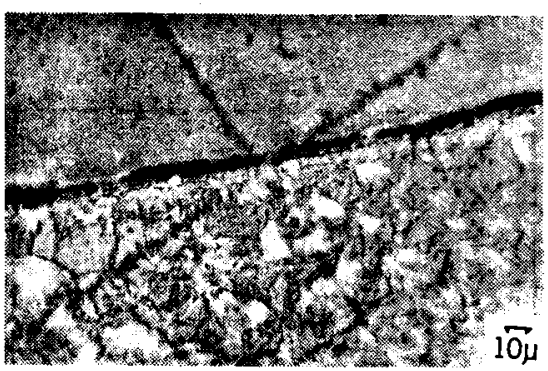

(C) IPP filled with 0.5 wt $\%$ azelaic acid (Peel strength $: 5.5 \mathrm{~kg} / 10 \mathrm{~mm}$ )

Plate 1 Cross section of IPP

球晶が認められた。

IPP にこれらの添加物を加えたものの表面状態をみると，グル

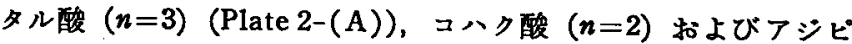
ン酸 $(n=4)$ 添加物（ともにグルタル酸添加物に近い表面を示す ため写真を省略）のように，表面は徽細な粗面となる。これに対 してマロン酸 $(n=1)$ (Plate 2-(B)) では丘状の大きな起伏を 生じ，その起伏の幅は球晶の直径とほぼ等しい。

以上のように IPP の熱処理物とジカルボン酸添加物について， 表面処理後のはく離強さ，結晶状態および表面あらさなどの間に 相関が認められたので，はく離強さと球晶直径をジルボン酸の メチレン鎖数 $n$ に対してプロットして図 3 を得た。図のよ5に $n=2 \sim 4$ の領域ではく離強さは極大値をとり, 球晶直径は便小値 をとって両者の間に相関が認められる。

IPP の加熱空気による表面処理もはやり酸化反応であり ，そ の結果カルボニル基のよらな極性基の生成が考えられる。しかし この表面の極性基は ATRのような方法によっては明確に検出す ることはできない。文献ですATR を試みたものはあるが，極性 基の確認や定量に成功したるのは見あたらない。

したがって著者らは既報2のよらにポリプロピレンの表面酸化 をやや強く行ない，梗珄基がその内部までおよぶ状態で透過法 


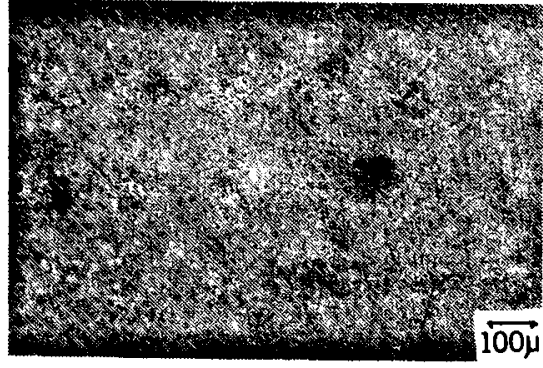

(A) IPP filled with 0.5 wt $\%$ glutaric acid (Peel strength : $7 \mathrm{~kg} / 10 \mathrm{~mm}$ )

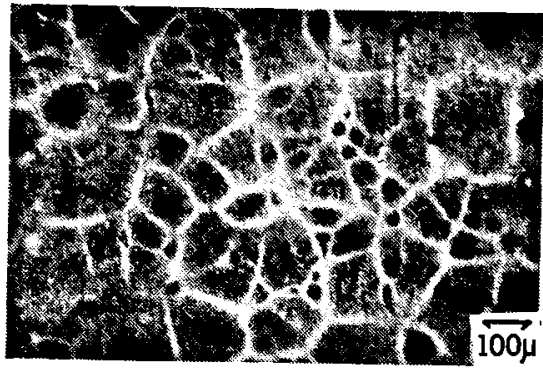

(B) IPP filled with 0.5 wt\% malonic acid (Peel strength : $2 \mathrm{~kg} / 10 \mathrm{~mm}$ )

Plate 2 Reflection micrograph of IPP

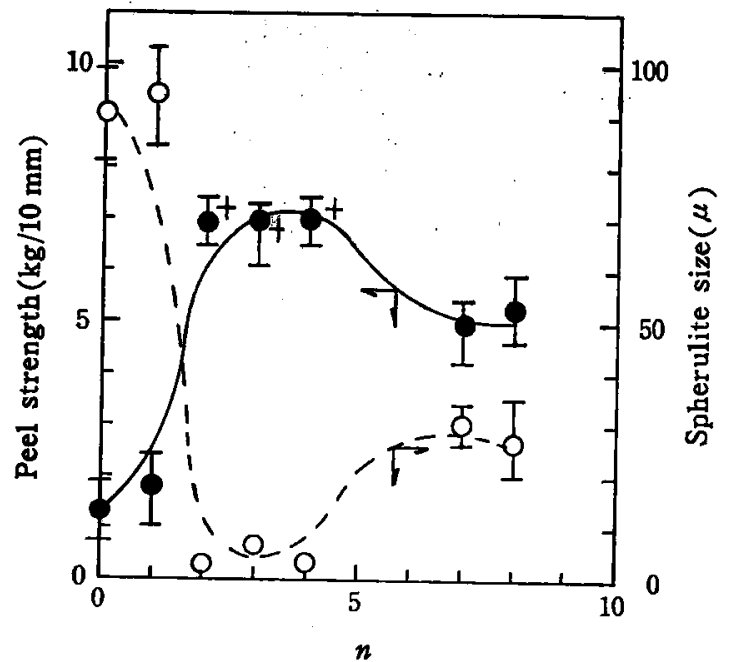

Fig. 3 Peel strength and spherulite size of IPP filled with 0.5 wt $\%\left(\mathrm{CH}_{2}\right)_{n}(\mathrm{COOH})_{2}, \quad(n=0,1,2,3,4,7,8)$

$n=0:$ Oxalic acid, $n=1:$ Malonic acid, $n=2:$ Succinic acid, $n=3$ : Glutaric acid, $n=4:$ Adipic acid, $n=7$ :

Azelaic acid, $n=8:$ Sebacic acid

$+:$ Adherend failure

による赤外吸収スペクトルから極性基を検出する方法を選んだ。

すなわち 2,4-ジニトロフェニルヒドラジンのよらな試剤によ ク，カルボニル基を有色ジニトロフェニルヒドラゾンとして検出 することとした。Plate 3-(A) には溶融後徐冾して球晶を発達さ せたIPP を，加熱空気処理したのちにヒドラン゙ンとしたものの断 面を示し, Plate 3-(B) にはフジピン酸を添加して同一時間同一 処理を行なったものの断面を示した。写真に明らかなよらに徐冷 したIPP の着色層は表面から内部に 10〜20 ピン酸添加物は 1〜2,

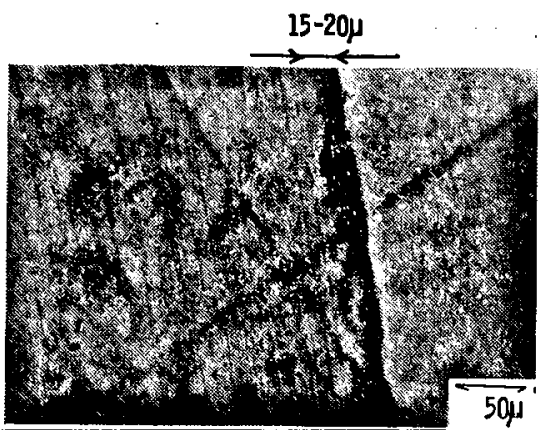

(A) IPP (annealed)

(2, 4-Dinitrophenylhydrazone)

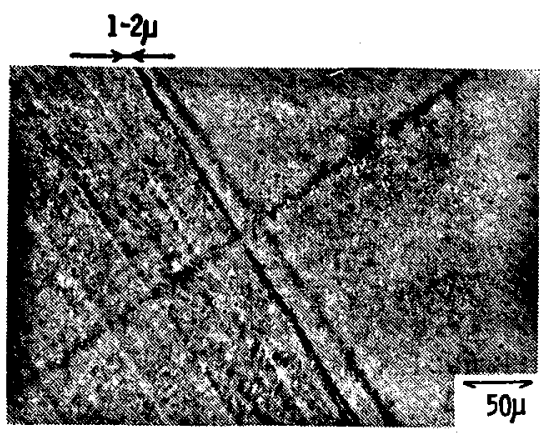

(B) IPP filled with adipic acid (2,4-Dinitrophenylhydrazone)

Plate 3 Cross section of hot air treated IPP

フェニルヒドラゾンを示し，加熱空気によりどの程度 IPP 内部ま でカルボニル基が生成されたかを示している。

この条件下で透過法によって検出されたカルボニル基の濃度が 同程度ならば, 徐冷した IPP よりあアジ゚ン酸添加 IPP の方が 表面層におけるカルニル基濃度は高くなるむのと考えられ，多少 のカルボニル基濃度差がある場合にるこの傾向は維持されるであ ろら。これにとあなって表面のぬれ方改善され，接着強さも上昇 するあのと考克られる。

\section{$3.3 \mathrm{X}$ 楾散乱図との関係}

IPP の加熱空気による表面処理と試料の結晶状態との相関がか なり明らかになったので，熱処理後徐冷したIPP と，有機ジ ルボン酸派加物のX線散乱図を求めた。各ピークの㷌属はWeidingerてにしたがった。

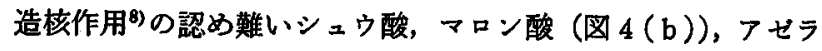
イン酸およびセバチン酸はアニールしたIPP（図 $5(\mathrm{~b})$ ) に近い 散乱図を示す。これに対して造核作用の顕著なコハク酸（図 5 (a)),グルタル酸扰よびアジピン酸（図4（a)）はいずれる (040) $\left(2 \theta=17^{\circ}\right)$ の反射ピークの強度がいちじるしく高い。

ここで (040) 面の反射の強さを $2 \theta=10^{\circ}$ と $2 \theta=27^{\circ}$ を結ぶ直 線に対する高さと仮定し，その值とはく離強さをプロットして四 6 を得た。図のように $\alpha, \omega$-ジカホホン酸のメチレン鎖の数 $n=$ 0〜8 の領域では $n=2 \sim 4$ ではく離強さも(040) 面の強度もとも に極大值をとる。しかるn=0〜8 領域全部にわたって両者の間に はかなりよい相関がみられる。

つぎに球晶值径と (040) 面の強度を $n=0$ ～8 領城プロットし

7) A. Weidinger, Makromol.Chem., 50, 452(1967).

8) H. N. Beck, J. Appl. Polym. Sci., 9, 2131 (1965). 


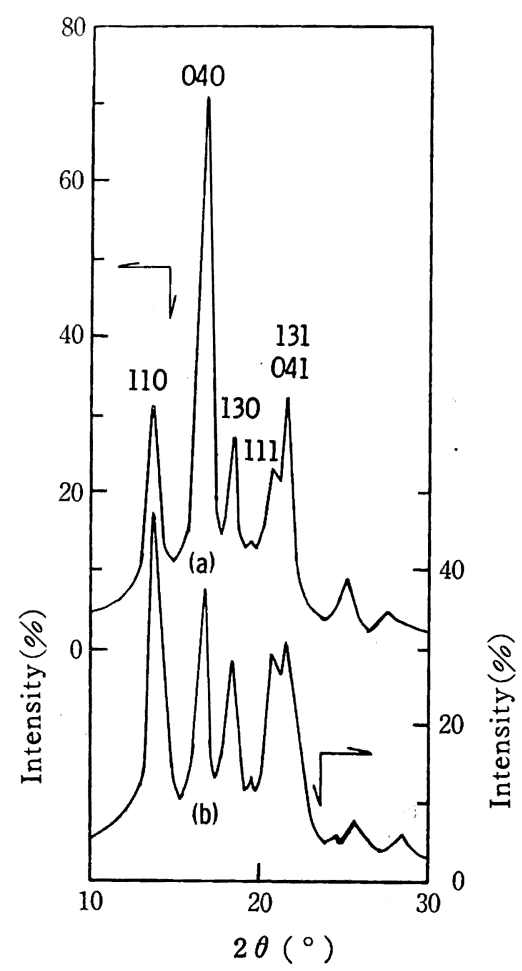

Fig. 4 X-ray diffraction scan of IPP (a) : Filled with adipic acid $(0.5 \mathrm{wt} \%)$

(b) : Filled with malonic acid $(0.5$ wt $\%)$

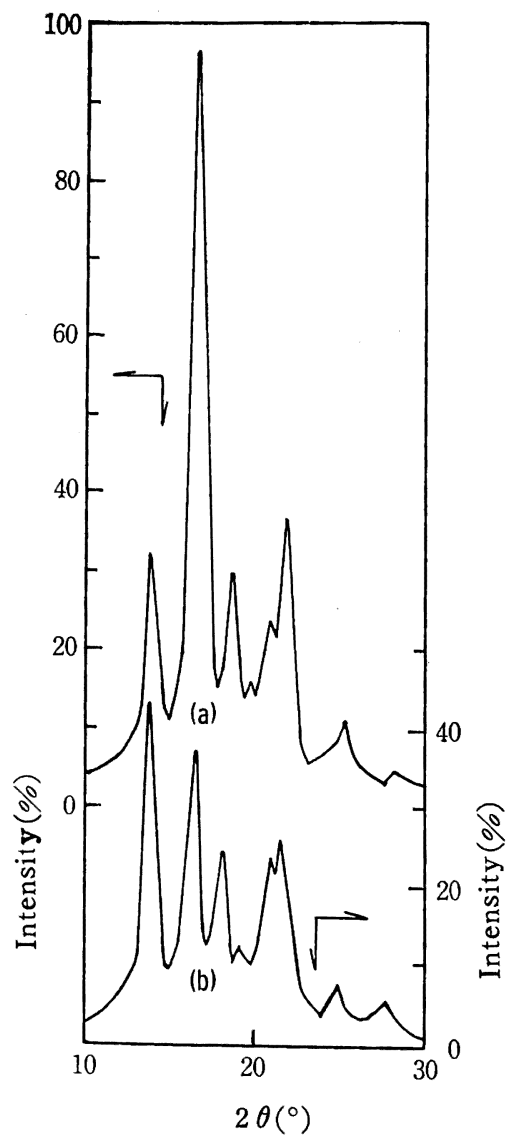

Fig. 5 X-ray diffraction scan of IPP

(a) : Filled with succinic acid $(0.5 \mathrm{wt} \%)$

(b) : Annealed

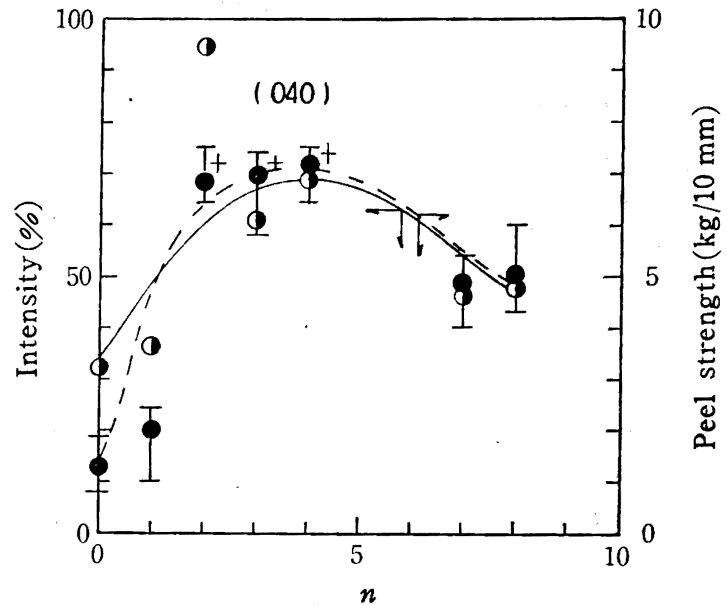

Fig. 6 Diffracted $\mathrm{X}$-ray intensities and peel strength of IPP filled with 0.5 wt $\%\left(\mathrm{CH}_{2}\right)_{n}(\mathrm{COOH})_{2}(n=0$,

$1,2,3,4,7,8)$.

$n=0:$ Oxalic acid, $n=1:$ Malonic acid, $n=2:$ Succinic acid, $n=3$ : Glutaric acid, $n=4:$ Adipic acid, $n=7$ : Azelaic acid, $n=8:$ Sebacic acid $+:$ Adherend failure

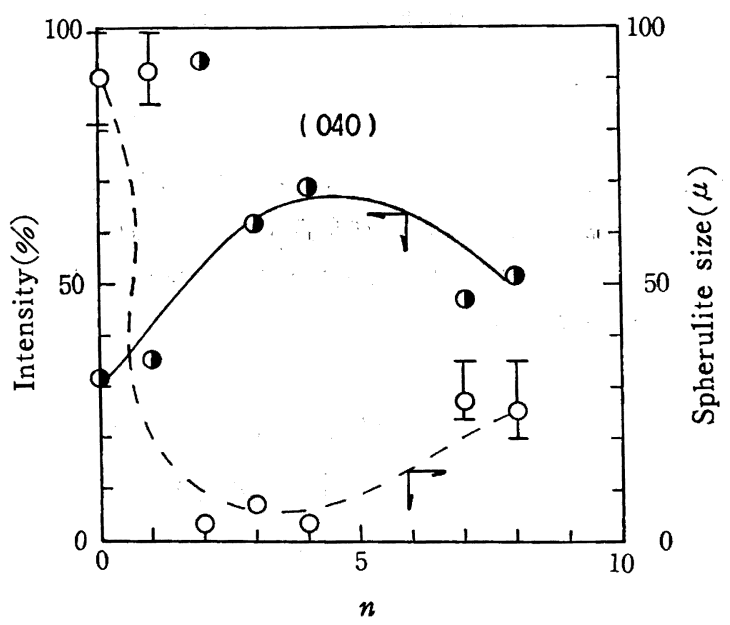

Fig. 7 Diffracted X-ray intensities and spher ulite size of IPP filled with $0.5 \mathrm{wt} \%\left(\mathrm{CH}_{2}\right)_{n}(\mathrm{COOH})_{2}(n=0$, $1,2,3,4,7,8)$

$n=0:$ Oxalic acid, $n=1:$ Malonic acid, $n=2:$ Succinic acid, $n=3$ : Glutaric acid, $n=4:$ Adipic acid, $n=7$ : Azelaic acid, $n=8:$ Sebacic acid

て困 7 を得た。図のように $n: 2 \sim 4$ の領域で反射強度は最大と なり，球晶直径は最少となった。すなわち添加するジカルボン酸 のメチレン鎖の数により球晶の直径や反射強度が支配され，図 6 の結果では同じ $n: 2 \sim 4$ の領域ではく離強さの極大值が得られ ている。

\section{4 添加物の構造とその作用}

加熱空気処理した IPP の接着性や表面の如やすさと，多塩 基性酸のメチレン鎖数の数および球晶構造などとの間には前に述 べたよらな相関が認められた。

表 1 には添加されたジカルボン酸およびその塩の構造と, 生成 する球晶の直径を示した。表のよらにメチレン鎖のくり返し数 $n=2 \sim 4$ のものの造核作用がもっとも強く, 生成する球晶直径も 
Table 1 Structure of nucleating agent and spherulite size of IPP

\begin{tabular}{lcc} 
Nucleating agent & $\begin{array}{c}\text { Number of repeated } \\
\text { unit }\end{array}$ & $\begin{array}{c}\text { Spherulite } \\
\text { size }(\mu)\end{array}$ \\
\hline Oxalic acid $(\mathrm{COOH})_{2}$ & 0 & 100 \\
Malonic acid $\mathrm{CH}_{2}(\mathrm{COOH})_{2}$ & 1 & 100 \\
Succinic acid $\left(\mathrm{CH}_{2}\right)_{2}(\mathrm{COOH})_{2}$ & 2 & $1 \sim 5$ \\
Glutaric acid $\left(\mathrm{CH}_{2}\right)_{3}(\mathrm{COOH})_{2}$ & 3 & $5 \sim 10$ \\
Adipic acid $\left(\mathrm{CH}_{2}\right)_{4}(\mathrm{COOH})_{2}$ & 4 & $1 \sim 5$ \\
Azelaic acid $\left(\mathrm{CH}_{2}\right)_{7}(\mathrm{COOH})_{2}$ & 7 & 30 \\
Sebacic acid $\left(\mathrm{CH}_{2}\right)_{8}(\mathrm{COOH})_{2}$ & 8 & 30 \\
Sodium succinate $\left(\mathrm{CH}_{2}\right)_{2}(\mathrm{COONa})_{2}$ & 2 & 100 \\
Sodium adipate $\left(\mathrm{CH}_{2}\right)_{4}(\mathrm{COONa})_{2}$ & 4 & 100 \\
Nil (IPP annealed) & - & 100
\end{tabular}

Table 2 Structure of nucleating agent and spherulite size of IPP

Nucleating agent

Spherulite $\operatorname{size}(\mu)$

Maleic acid $(\mathrm{CHCOOH})_{2}$ 100

Succinic acid $\left(\mathrm{CH}_{2}\right)_{2}(\mathrm{COOH})_{2}$

$1 \sim 5$

Terephthalic acid $\mathrm{HOOC}-\longrightarrow-\mathrm{COOH}$

100

1, 4-Cyclohexanedicarboxylic acid

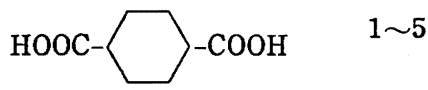

Nil(IPP annealed)

100

ほとんど $5 \mu$ 前後であった。これに対して造核作用の弱い $n: 7$ 〜8のものを添加した場合には球晶直径は $30 \mu$ 前後となり, 造 核作用をもたない $n: 0 〜 1$ のものを添加した場合の球晶直径は, いずれも $100 \mu$ 前後を示した。
また顕著な造核能をもつコハク酸 $(n=2)$ およびアジピン酸 $(n=4)$ をナトリウム塩とするとその造核能は失われ，添加物の 球晶直径はいずれす $100 \mu$ 前後を示した。

つぎにこれらのジカルボン酸に芳香核，脂環核および不飽和結 合を導入したと考えられるテレフタル酸, シクロへキサンジカル ボン酸拉よびマレイン酸の例を表 2 に示した。

飽和鎖をむつコハク酸 $(n=2)$ は強い造核能を示し, 球晶直径 も $5 \mu$ 前後となるが，これに不飽和結合を導入したマレイン酸 $(n=2)$ では造核能は失われ，球晶直径も $100 \mu$ 前後を示した。

脂環構造をもつ 1,4-シクロヘキサンジカルボン酸では顕著な 造核能が現われ，球晶直径も5 4 前後になるのに対して，脂環骨 核を芳香核に置换したテレフタル酸では造核能は消失し, 球晶直 径も $100 \mu$ 前後となった。

4 結

論

ポリプロピレンは加熱空気によってほとんど脆化をともなわず に接着性の改善された処理表面を与学る。このさい熱処理または 有機ジカルボン酸添加によってその処理効果を促進させることが できる。

この促進作用はポリプロピレンの結晶状態と相関をもつ。また ポリプロピレンに対して造核能のあるジカルボン酸を与えると微 細な球晶を生じ，ポリプロピレン表面も微粗面となる。これに対 して造核作用のないジカルボン酸添加物は球晶直径はきわめて大 きく，その表面も球晶直径と同程度の大きな突起を生ずる。

これらの変化を通じて加熱空気処理されたポリプロピレンの接 着強さ, 臨界表面張力, 球晶直径, 表面状態, 極性基生成量およ びジカルボン酸の化学構造などの間に相関を見いだすことができ た。

\section{Effect of Hot Air Treatment on Bond Strength of Isotactic Polypropylene in the Presence of Dicarboxylic Acid}

Masaki Shimbo, Tetsuji Kitamura and Hiroshi Kida

Faculty of Engineering, Kansai University ;

Senriyama-higashi, Suita-shi 564 Japan

Isotactic polypropylene was treated with hot air without chain scission, resulting in good bondability.

Organic dicarboxylic acids having 0 8 methylene linkages were added to polypropylene, and subjected the same treatment, resulting in maximum value of peel strength between $2 \sim 4$.

Under the same conditions, minimum value of the spherulite diameter and maximum value of reflection intensity on (040) surface by X-ray diffraction pattern were also observed. 